\section{MANNITOL BUSULPHAN IN DISSEMINATED BREAST CARCINOMA}

BY

\author{
EVELYN BOESEN, M.B., B.S. \\ Royal Free Hospital, London
}

The search continues for effective chemotherapeutic agents in the treatment of disseminated carcinoma. Some patients with disseminated carcinoma of the breast have responded to treatment with alkylating agents (Wright, Golomb, and Gumport, 1958; Olson, 1958 ; Moore, 1958 ; Gurling, 1959). The following is a report of the clinical effects of therapy with a hitherto untried alkylating agent, mannitol busulphan (mannitol myleran ; C.B.2511).

\section{Clinical Material}

Patients with extensive carcinoma of the breast or prostate are referred here for consideration for hypophysectomy, which is undertaken only when disease is disseminated or when extensive inoperable local disease is present. In all, 15 patients have received mannitol busulphan; 14 of these had undergone previous hypophysectomy. Mannitol busulphan was given when evidence was obtained of renewed progression of disease after hypophysectomy or when it became clear that hypophysectomy had failed to influence the continued progression of disease. Of the 15 patients treated, 11 with extensive breast carcinoma received enough of the drug to produce bone-marrow depression. Four patients-three with breast carcinoma and one with disseminated carcinoma of the prostate-received small doses of mannitol busulphan preterminally and all died within a month of starting therapy. These four cases are shown in Table I, but are not further discussed.

Among the 11 patients who received adequate therapy widely disseminated disease was present in 10 (Table II). One patient who had an extensive recurrence in the scar area 18 months after radical mastectomy was treated with mannitol busulphan prior to pituitary ablation. She had failed to respond to earlier hormone therapy. This patient was hypertensive and had had a myocardial infarct after radical mastectomy.

Reponse to previous hypophysectomy had occurred in five patients and five had failed to obtain even temporary remission after hypophysectomy, but four of the latter had obtained earlier remissions of disseminated disease after other hormonal therapy. Those patients who had undergone hypophysectomy were receiving replacement therapy, usually $0.2 \mathrm{mg}$. of thyroxine and 50-75 mg. of oral cortisone acetate daily.

Histological confirmation of carcinoma was present in all but two patients (Table III)-one of these (Case 9) had undergone radical mastectomy over 15 years previously in another country, the other (Case 1) had extensive bilateral breast masses which had been treated with radiotherapy some months before referral. An estimate of the growth rate of the tumour as slow, medium, or fast was made in each patient, on the basis of the clinical condition when seen and the past history.

\section{The Drug}

The alkylating agent used in the treatment of these patients was D-mannitol busulphan (Timmis and Brown, 1960) (Fig. 1) which was prepared and made available by G. M. Timmis and S. S. Brown of the Chester Beatty Research Institute. Studies of the drug in experimental animals had indicated a wide spectrum of

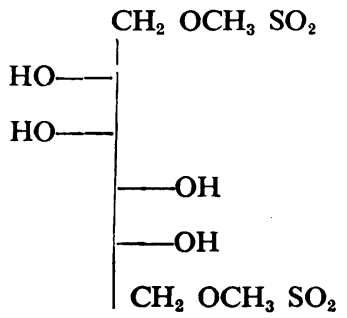

FIG. 1.-D-Mannitol busulphan.

activity, with low general toxicity, and more especially low toxicity to the bone-marrow. In this series the drug was given only by the intravenous route in 10 of the 11 cases. One patient (Case 6) received the drug intraperitoneally at first and by intravenous injection later. The dry powder was dissolved immediately before administration and given as single doses of 2-4 g. in $20-40 \mathrm{ml}$. of sterile water in two to three minutes. Solution of the drug in water was rather slow but could be hastened by shaking and slightly warming the container.

The following dosage schedules were used. In cases 1-5 therapy was started with doses of $3 \mathrm{~g}$. three times a week and was continued until a fall in total white-cell count occurred. The dosage was then reduced. Four patients (Cases 8-11) received 3-4 g. daily for three to four days ; this caused severe bone-marrow damage. One patient (Case 6) received a single intraperitoneal dose of $17 \mathrm{~g}$. Case 7 received $15 \mathrm{~g}$. over 12 days. This dosage produced severe bone-marrow damage, and she is grouped together with those cases in which a similar effect was produced (Cases 6, 8, 9, 10, and 11). Main-

TABLE I.-Patients Considered to Have Received Inadequate Therapy

\begin{tabular}{|c|c|c|c|c|c|c|c|c|c|}
\hline \multirow[b]{2}{*}{ Case } & \multirow{2}{*}{$\begin{array}{l}\text { Age } \\
\text { in } \\
\text { Years }\end{array}$} & \multirow[b]{2}{*}{ Summary of History } & \multirow{2}{*}{$\begin{array}{c}\text { Period } \\
\text { of } \\
\text { Treatment }\end{array}$} & \multirow{2}{*}{$\begin{array}{l}\text { Dosage } \\
\text { and } \\
\text { Route }\end{array}$} & \multirow[b]{2}{*}{$\begin{array}{l}\text { Total } \\
\text { Dosage }\end{array}$} & \multicolumn{3}{|c|}{ Toxic Effects } & \multirow[b]{2}{*}{ Results } \\
\hline & & & & & & Marrow & $\begin{array}{c}\text { Nausea } \\
\text { and } \\
\text { Vomiting }\end{array}$ & Alopecia & \\
\hline $\mathbf{A}$ & 35 & $\begin{array}{l}\text { 8/6/60: hypophysectomy for dissemin- } \\
\text { ated carcinoma of breast - no response }\end{array}$ & $26 / 5-6$ & $\begin{array}{l}\text { Intravenous } \\
2 \mathrm{~g} \cdot \times 3 \\
\text {. }\end{array}$ & $12 \mathrm{~g}$. & + & - & - & Subjective: nil. Objective: shrink- \\
\hline $\mathbf{B}$ & 57 & $\begin{array}{l}\text { Oct., } 1958 \text { : radical mastectomy. Dec., } \\
1959 \text { : hypophysectomy for dissemin- } \\
\text { ated disease, with response }\end{array}$ & $20 / 4 / 61$ & $\begin{array}{l}\text { weekiy } \\
\text { Intravenous } \\
2-3 \text { g. } \\
\text { weekly }\end{array}$ & 6, & - & - & - & $\begin{array}{l}\text { lesions unaffected. Died } 8 / 6 / 60 \\
\text { Subjective: decrease in bone pain. } \\
\text { Objective: nil. Died } 25 / 4 / 61\end{array}$ \\
\hline $\mathbf{D}$ & 60 & $\begin{array}{l}\text { 1959: oestrogen therapy for dissemin- } \\
\text { ated carcinoma of prostate. Sept., } \\
\text { 1960: hypophysectomy }\end{array}$ & $30 / 10 / 60$ & $\begin{array}{l}\text { Intravenous } \\
3 \mathrm{~g} . \times 3 \\
\text { weekly }\end{array}$ & $6, "$ & + & - & - & $\begin{array}{l}\text { Subjective: slight pain relief. } \\
\text { Objective: nil. Died from pro- } \\
\text { gression of disease } 2 / 11 / 60\end{array}$ \\
\hline
\end{tabular}


tenance therapy with small weekly doses of 1-3 g. was begun in all patients when the bone-marrow had recovered.

\section{Toxic Effects}

In three cases nausea and vomiting occurred 3 to 24 hours after a dose was administered. In one of these severe nausea and vomiting accompanied by diarrhoea followed a single large intraperitoneal dose. One patient vomited after each intravenous dose of $3 \mathrm{~g}$., and the remaining patient, a very anxious woman, complained of nausea sometimes accompanied by vomiting after each dose of over $0.5 \mathrm{~g}$.

Damage to the bone-marrow occurred in all patients. In those given 6-9 g. weekly in divided doses, depression of the white blood count occurred about three weeks after the start of therapy, followed rapidly by recovery of the count on withdrawal of the drug or reduction in dose. This is illustrated in Fig. 2. The granulocytes were depressed chiefly, and in one patient (Case 4) graduated doses resulted in fatal agranulocytosis. This patient, however, had received treatment with another alkylating agent, chlorambucil, eight months previously.

Cases 6-11 who received large doses initially, over a short period of time, developed agranulocytosis. This developed two to three weeks after the start of therapy and lasted for 9 to 15 days. The haemoglobin concentration and platelet count also fell. The lymphocyte counts were relatively less depressed

TABLE II

\begin{tabular}{|c|c|c|c|c|c|c|c|c|c|}
\hline \multirow[b]{2}{*}{$\begin{array}{l}\text { Case } \\
\text { No. }\end{array}$} & \multirow{2}{*}{$\underset{\substack{\text { Ane } \\
\text { Years }}}{\text { Ageas }}$} & \multirow[b]{2}{*}{ Summary of History } & \multirow{2}{*}{$\begin{array}{c}\text { Period } \\
\text { of } \\
\text { Treatment }\end{array}$} & \multirow{2}{*}{$\begin{array}{l}\text { Dosage } \\
\text { and } \\
\text { Route }\end{array}$} & \multirow[b]{2}{*}{$\begin{array}{c}\text { Total } \\
\text { Dosage }\end{array}$} & \multicolumn{3}{|c|}{ Toxic Effects } & \multirow[b]{2}{*}{ Results } \\
\hline & & & & & & Marrow & $\left|\begin{array}{c}\text { Nausea } \\
\text { and } \\
\text { Vomiting }\end{array}\right|$ & Alopecia & \\
\hline 1 & 58 & $\begin{array}{l}\text { 20/12/56: radiotherapy bilaterally to } \\
\text { breast carcinomas. } 18 / 12 / 59: \\
\text { implant into pituitary for disseminated } \\
\text { disease-no response }\end{array}$ & $\begin{array}{c}7 / 3- \\
15 / 4 / 60\end{array}$ & $\begin{array}{c}\text { Intravenous } \\
2 \text { g. } \times 3 \\
\text { weekly; } \\
\text { then } 1-2 \mathrm{~g}\end{array}$ & $17 \cdot 5 \mathrm{~g}$. & + & - & - & $\begin{array}{l}\text { Subjective: +, relief of bone pain; } \\
\text { improvement general well-being. } \\
\text { Objective: nil. Died } 20 / 4 / 60 \text { of } \\
\text { pulmonary insufficiency second- }\end{array}$ \\
\hline 2 & 54 & $\begin{array}{l}\text { 28/4/54: radical mastectomy. } 25 / 9 / 56: \\
\text { hypophysectomy for disseminated } \\
\text { disease with good regression. Jan., } \\
\text { 1960: further osseous deposits }\end{array}$ & $\begin{array}{c}7 / 5 / 60 \\
\text { to present }\end{array}$ & $\begin{array}{l}\text { Intravenous } \\
2 \mathrm{~g} . \times 3 \\
\text { weekly; } \\
1 \mathrm{~g} .\end{array}$ & $\begin{array}{l}88 \mathrm{~g} . \\
\text { so far }\end{array}$ & + & + & - & $\begin{array}{l}\text { Subjective: }+ \text {; relief of bone pain. } \\
\text { Objective: lesions in pelvis and } \\
\text { femora have remained static. } \\
\text { Still alive }\end{array}$ \\
\hline 3 & 52 & $\begin{array}{l}\text { 7/8/58: radical mastectomy. Dec., } \\
\text { 1959: local recurrence in scar. Worse } \\
\text { with oestrogen }\end{array}$ & $\begin{array}{l}24 / 8- \\
16 / 12 / 60\end{array}$ & $\begin{array}{l}\text { Intravenous } \\
2 \mathrm{~g} \cdot \times 3 \\
\text { weekly; } \\
1-2 \mathrm{~g} \text {. }\end{array}$ & $33 \mathrm{~g}$. & + & - & - & $\begin{array}{l}\text { Subjective: no symptoms. Objec- } \\
\text { tive: slowing rate of progression } \\
\text { of ulcers. }{ }^{\circ} \mathrm{Y} \text { implant } 8 / 2 / 61\end{array}$ \\
\hline 4 & 59 & $\begin{array}{l}\text { 18/5/59: disseminated carcinoma of } \\
\text { breast discovered. Regression with } \\
\text { androgens. 18/6/60: chlorambucil } \\
\text { therapy-no response. 26/8/60: hypo- } \\
\text { physectomy-no response }\end{array}$ & $\begin{array}{l}3 / 10 \\
10 / 10 / 60\end{array}$ & $\begin{array}{l}\text { weekly } \\
\text { Intravenous } \\
2-3 \text { g. } \times 3 \\
\text { weekly }\end{array}$ & $11 \mathrm{~g}$. & $+t+$ & - & - & Died $16 / 10 ; 60$ of agranulocytosis \\
\hline 5 & & $\begin{array}{l}\text { 25/10/57: radical mastectomy. 1958: } \\
\text { disseminated disease-regression with } \\
\text { androgens and corticosteroids. 17/8/60: } \\
\text { hypophysectomy-no response }\end{array}$ & $\begin{array}{l}7 / 10 \\
10 / 11 / 60\end{array}$ & $\begin{array}{c}\text { Intravenous } \\
3 \mathrm{~g} . \times 3 \\
\text { weekly; } \\
1 \mathrm{~g} . \text { weekly }\end{array}$ & $18 \cdot 5 \mathrm{~g}$ & + & - & - & $\begin{array}{l}\text { Subjective: not definite. Objec- } \\
\text { tive: healing and regranulation } \\
\text { of chest-wall ulcers. Temporary } \\
\text { improvement. Died 2/2/61 }\end{array}$ \\
\hline 6 & 55 & $\begin{array}{l}19 / 2 / 53 \text { : radical mastectomy. } 30 / 8 / 59: \\
\text { oophorectomy for malignant ascites. } \\
17 / 5 / 60: \text { hypophysectomy-temporary } \\
\text { response }\end{array}$ & $\begin{array}{r}7 / 10 / 60 \\
\text { to present }\end{array}$ & $\begin{array}{l}\text { Intraperiton- } \\
\text { eal } 16.75 \mathrm{~g} . \\
8 \text {-weeks } \\
\text { interval. } \\
\text { Intravenous } \\
1-3 \mathrm{~g} \text {. wkly }\end{array}$ & $\begin{array}{l}49 \cdot 75 \mathrm{~g} \\
\text { so far }\end{array}$ & ++ & + & + & $\begin{array}{l}\text { Subjective: }+ \text {; Objective: shrink- } \\
\text { age of glands; decrease in } \\
\text { ascites. Still alive }\end{array}$ \\
\hline 7 & 49 & $\begin{array}{l}\text { 5/9/58 : radical mastectomy. Dec., } 1959: \\
\text { 00 Y pituitary implant for disseminated } \\
\text { disease with good regression }\end{array}$ & $\begin{array}{l}17 / 12 / 60 \\
\text { to present }\end{array}$ & $\begin{array}{c}\text { Intravenous } \\
3-4 \text { g. } \times 3 \\
\text { weekly; } 1- \\
2 \text { g. weekly }\end{array}$ & $\begin{array}{l}41 \mathrm{~g} . \\
\text { so far }\end{array}$ & ++ & - & - & $\begin{array}{l}\text { Subjective: decrease in bone pain. } \\
\text { Objective: decrease in size of } \\
\text { pulmonary lesions; osseous le- } \\
\text { sions; static. Still alive }\end{array}$ \\
\hline 8 & 35 & $\begin{array}{l}\text { 29/12/55: radical mastectomy. } 16 / 5 / 56: \\
\text { oophorectomy with regression. 15/5/58: } \\
\text { adrenalectomy, with regression. } \\
17 / 10 / 60 \text { : hypophysectomy }\end{array}$ & $218 / 1 / 61$ & $\begin{array}{l}\text { Intravenous } \\
3 \text { g. daily } \\
\times 4\end{array}$ & $14 \mathrm{~g}$. & ++ & - & - & $\begin{array}{l}\text { Subjective: some decrease in bone } \\
\text { pain. Objective: no evidence } \\
\text { regression. Died } 19 / 7 / 61\end{array}$ \\
\hline 9 & 64 & $\begin{array}{l}\text { 1944: radical mastectomy. 1957: } \\
\text { steroid therapy for disseminated } \\
\text { disease-resulting regression. 29/9/60: } \\
\text { hypophysectomy-no response }\end{array}$ & $\begin{array}{c}16 / 1- \\
20 / 1 / 61\end{array}$ & $\begin{array}{l}\text { Intravenous } \\
4 \text { g. daily } \\
\times 3\end{array}$ & $14 \mathrm{~g}$. & ++ & - & - & $\begin{array}{l}\text { Subjective: decrease in pain due to } \\
\text { brachial plexus involvement. } \\
\text { Objective: nil. Died 12/2/61 } \\
\text { from bronchitis when W.B.C. }\end{array}$ \\
\hline 10 & 50 & $\begin{array}{l}\text { March, 1956: radiotherapy to breast } \\
\text { and glands. June, 1957: hypo- } \\
\text { physectomy, good response. Jan., } \\
\text { 1961: new skin deposit }\end{array}$ & $\begin{array}{l}30 / 5 / 61 \\
\text { to present }\end{array}$ & $\begin{array}{l}\text { Intravenous } \\
3 \text { g. daily } \\
\times 4 \text { days. } \\
\text { Then } 1-\end{array}$ & $\begin{array}{l}22 \mathrm{~g} \text {. } \\
\text { so far }\end{array}$ & ++ & - & - & $\begin{array}{l}\text { Subjective: no symptoms. Objec- } \\
\text { tive: decrease in size of breast } \\
\text { and skin lesions. Still alive }\end{array}$ \\
\hline 11 & 60 & $\begin{array}{l}\text { March, 1959: radical mastectomy. } \\
20 / 7 / 60: \text { hypophysectomy for dis- } \\
\text { seminated disease-good response }\end{array}$ & $\begin{array}{l}29 / 6 / 61 \\
\text { to present }\end{array}$ & $\begin{array}{l}\text { Intravenous } \\
3 \mathrm{~g} . \text { daily } \\
\times 41-2 \mathrm{~g} \\
\text { weekly }\end{array}$ & $\begin{array}{l}15 \mathrm{~g} . \\
\text { so far }\end{array}$ & ++ & + & + & $\begin{array}{l}\text { Subjective: complete relief of bone } \\
\text { pain. Objective: not confirmed. } \\
\text { Still alive }\end{array}$ \\
\hline
\end{tabular}

TABLE III

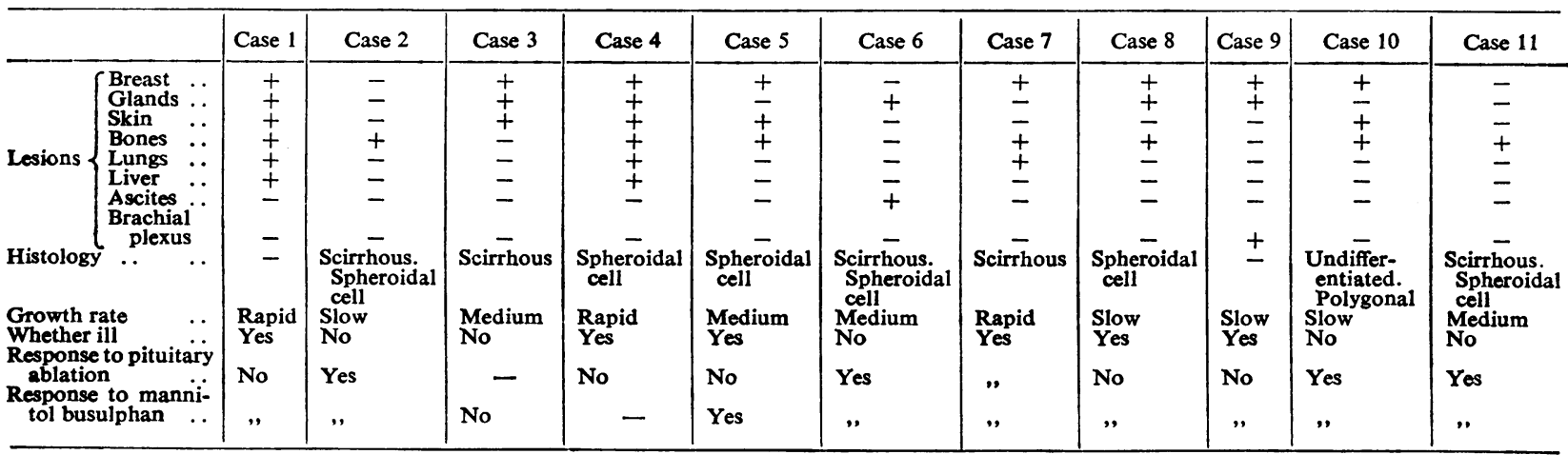


(Fig. 3). The production of prolonged neutropenia was deliberate. From the experience gained from the patients initially treated in this series bone-marrow depression was expected to occur. The total dose of
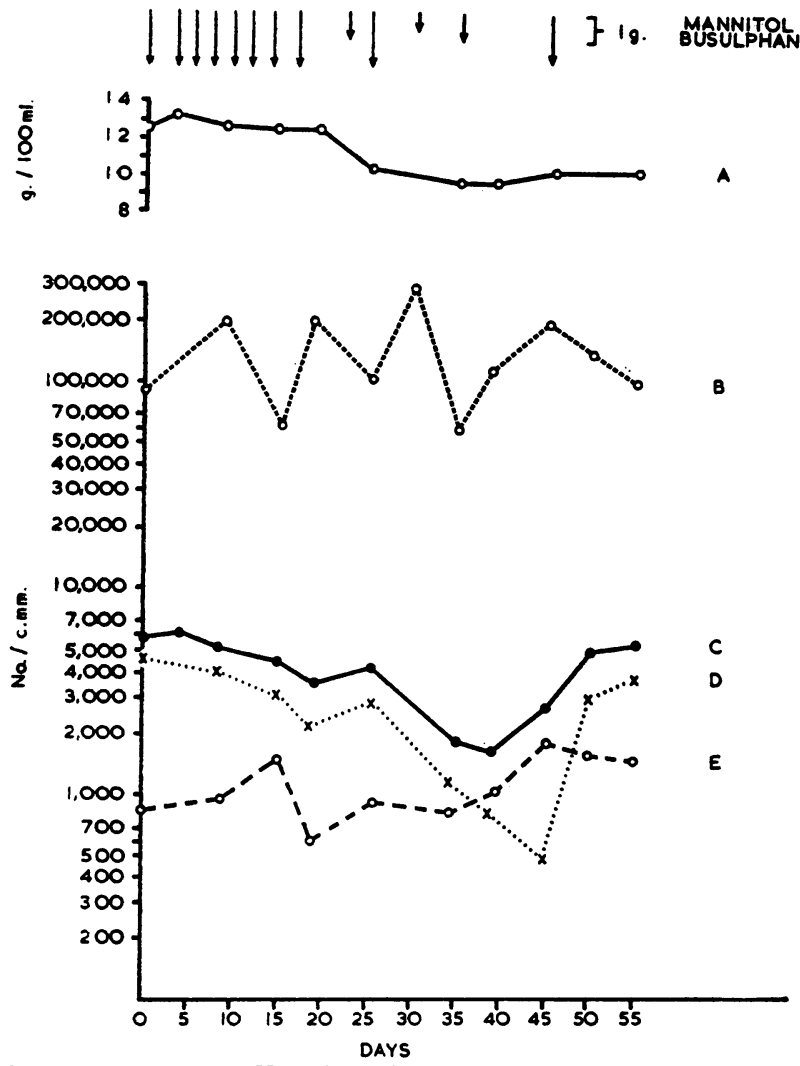

Fio. 2.-Case 2. (Key for Figs. 2 and 3. A=Haemoglobin $\mathbf{B}=$ Platelet count. $\quad \mathbf{C}=$ Total white-cell count. $\quad \mathrm{D}=$ Polymorphonuclear leucocyte count. $E=$ Lymphocyte count.)

$$
\text { III }\} \text { Ig. MANNITOL }
$$
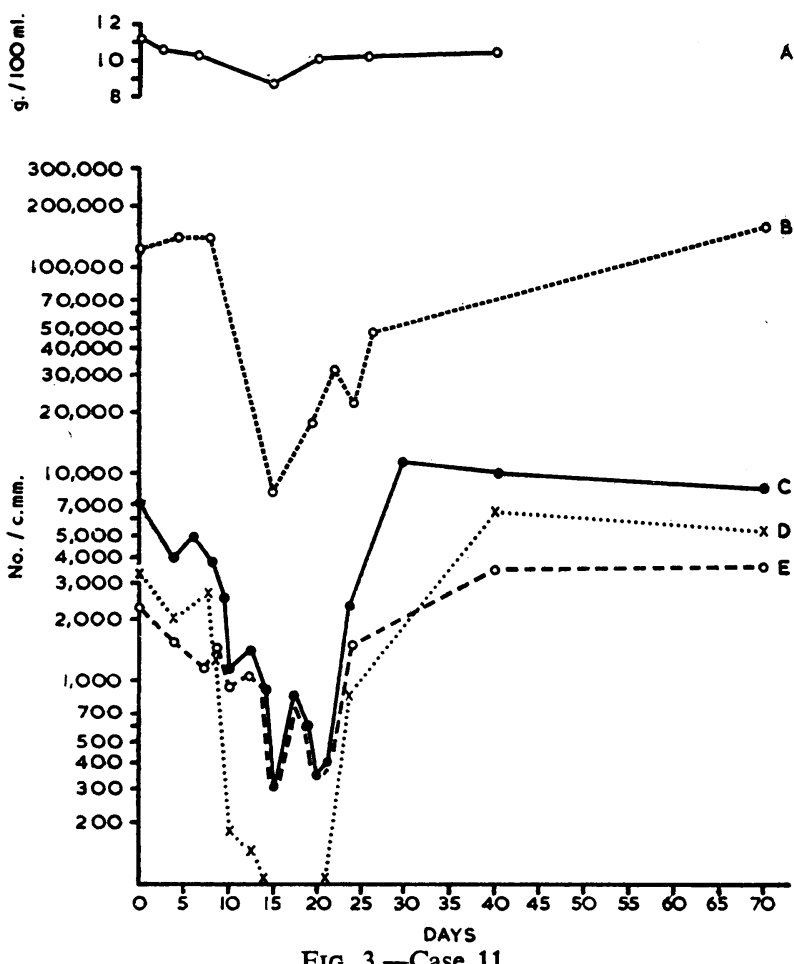

drug given over a short period was that thought to be the maximal possible which the patient could survive. Throughout the period of agranulocytosis these patients were treated with cortisone at an increased dosage of $100-200 \mathrm{mg}$. daily. Antibiotics were given only when definite evidence of infection was found. Fresh blood from a platelet pack was given when agranulocytosis had been present for several days, if general malaise was severe and the platelet count and haemoglobin concentration were low. Cases 6-11 had each undergone functionally complete pituitary ablation as assessed by standard methods (Baron and Gurling, 1959), and their care during the period of agranulocytosis became complicated because often anorexia and failure to eat resulted in hypoglycaemia.

On recovery the blood count rose very rapidly and all the affected components recovered completely.

Alopecia developed in two patients who had prolonged agranulocytosis. Regrowth of head hair took place slowly in the succeeding months.

\section{Response}

Objective response to therapy as assessed by the standard methods used here (Boesen, Radley Smith, and Baron, 1961) occurred in 5 of the 11 patients treated.

Two of cases 1-5 who were given graduated weekly doses responded to therapy. In one (case 5) a decrease in bone pain occurred and the re-epithelization of extensive chest-wall ulcers started. However, the improvement lasted for six weeks only. The second patient (case 2) has extensive osteolytic lesions. This patient is still receiving mannitol busulphan after 17 months of treatment. Bony lesions have not recalcified while she has been on therapy, but she has had complete relief from severe bone pain. No new osseous lesions have appeared while she has been receiving treatment, but bone pain has recurred two to three weeks after the temporary cessation of therapy on three occasions.

Three of six patients (cases 6-11) who received large initial doses of mannitol busulphan showed objective response to therapy. One of three patients in whom no objective evidence of response has yet occurred has been treated only recently, and so far has shown marked subjective improvement, with total relief of bone pain.

In three patients who improved after large initial doses, subjective evidence of improvement was apparent during the stage of agranulocytosis when this produced no symptoms, or was noted after recovery from agranulocytosis. In Case 7 bone pain was decreased, osseous lesions have remained static, and pulmonary lesions have decreased in size radiologically. In one patient (Case 6) who had ascites, peritoneal masses, and supraclavicular glands a single intraperitoneal dose of mannitol busulphan was given. On recovery from agranulocytosis, ascites did not recur for two months after discharge from hospital, and peritoneal masses decreased in size and glands became impalpable. Therapy with mannitol busulphan was resumed when ascites recurred and a pleural effusion developed. A small and probably insufficient dose of yttrium-90 was inserted intraperitoneally and removed after 48 hours. Intravenous injections of mannitol busulphan were administered weekly and the pleural effusion was resolved and ascites did not recur. The patient was still well and ascites, pleural effusion, and supraclavicular glands had not recurred 11 months after the start of treatment with mannitol busulphan. 
Small recurrent skin nodules decreased in size in a third patient treated with large doses of mannitol busulphan. One patient obtained relief of severe pain due to involvement of the brachial plexus, but no objective evidence of improvement was found. She died of bronchitis four weeks after treatment started, when her leucocytes, which had fallen to $450 / \mathrm{c} . \mathrm{mm}$., had recovered.

\section{Discussion}

Improvement and objective temporary remission of disseminated breast carcinoma has been obtained by the use of mannitol busulphan. Two of five patients given smaller doses obtained some benefit, and three, possibly four, of six patients who were given larger doses obtained objective improvement. It is probable that the degree of benefit depends on the amount of drug administered, and unless enough is given to damage the bone-marrow the effect on the growth is likely to be negligible.

Several reports of the treatment of disseminated carcinoma of the breast with alkylating agents have appeared. In most series between one-third and onefifth of the patients treated have responded (Moore, 1958; Gurling, 1959). It has been suggested that patients who respond well to other forms of treatment may have a better chance of benefiting from chemotherapy (Gurling, 1959). In all but one of the patients treated in this series response to mannitol busulphan has been similar to that which followed previous hypophysectomy. Hypophysectomy, however, was undertaken in some as a final hormonal resort, and response to chemotherapy is not similar in all cases to the response to hormonal therapy prior to hypophysectomy. The one patient (Case 3) on whom pituitary ablation was performed after treatment with mannitol busulphan obtained a better response to pituitary ablation than to the chemotherapy.

Persistent treatment with an alkylating agent may result in destruction of slightly more tumour cells in the marrow than bone-marrow cells, with a resulting small advantage to the patient.

Regression of disseminated carcinoma can be produced using mannitol busulphan, but it is difficult to say from such a small series whether this drug offers any advantage over other alkylating agents. No such advantage has become apparent as yet. It is possible that a small advantage is gained by treating patients to the limit of toxicity compared with the results obtained using a less drastic dosage schedule. This would suggest that, as with other similar agents, the effective dosage remains uncomfortably near to the lethal dosage, and close supervision of patients undergoing such therapy, possible only within a hospital, is essential.

\section{Summary}

Eleven patients with disseminated carcinoma of the breast were treated with a new alkylating agent, mannitol busulphan. Regression of disease occurred in four out of six patients given doses sufficient to produce severe bone-marrow depression. In two out of five patients given smaller doses temporary regression of disease also occurred.

No definite advantage of this drug over other similar agents is apparent.

Carefully supervised dosage sufficient to produce severe bone-marrow depression may produce improved response to treatment.
I thank Mr. E. J. Radley Smith for permission to publish these results obtained in patients under his care, and Dr. D. A. G. Galton and Dr. D. N. Baron for advice and encouragement. This work was supported by a grant from the British Empire Cancer Campaign.

\section{REFERENCES}

Baron, D. N., and Gurling, K. J. (1960). Recent Advances in Clinical Pathology, edited by S. C. Dyke, Series III, p. 140 Churchill, London.

Boesen, E., Radley Smith, E. J., and Baron, D. N. (1961). Brit. med. J., 2, 790 .

Gurling, K.' J.'(1959). Brit. J. Cancer, 13, 168.

Moore, G. E. (1958). Ann. N.Y. Acad. Sci., 68, 1074.

Olson, K. B. (1958). Ibid., 68, 1018

Timmis, G. M., and Brown, S. S. (1960). Biochem. Pharmacol. 3, 247.

Wright, J. C., Golomb, F. M., and Gumport, S. L. (1958). Ann. N.Y. Acad. Sci., 68, 937 .

\section{ISOLATED REGIONAL PERFUSION IN TREATMENT OF MALIGNANT DISEASE}

BY

OLIVER GARAI, M.R.C.P. Gordon Jacobs Research Fellow

CYRIL COOLING, F.R.C.S. Surgeon

AND

DUDLEY STAUNTON, F.R.C.S. Gordon Jacobs Research Fellow Royal Marsden Hospital, London

Isolated regional perfusion is a method of treating malignant disease and employs as anti-cancer agents cytotoxic or antimetabolic substances.

Many of the difficulties of treating malignant disease are inherent in the unique biological properties of malignant cells. These cells, though independent, share many properties with host cells; thus an effective anticancer agent is more than likely to produce an effect on the cells of the host similar to that which it exhibits on the cells of the tumour, though perhaps differing in degree.

Anti-cancer agents in use at the present time are either cytotoxic or hormonal, the former including both the alkylating agents and the antimetabolites. This communication is concerned only with the alkylating agents. To use these effectively some method is required to protect the host cells from their effect, particularly on such tissues as bone-marrow and alimentary tract.

From this basic requirement has grown the concept of isolated regional perfusion, which is an attempt to isolate a tumour in its own vascular bed from the remainder of the body's circulatory system. By this method the isolated tumour-bearing vascular territory is perfused with blood into which can be introduced the appropriate cytotoxic agent in such a manner as to maintain an effective concentration for a given period of time.

Continuous regional intra-arterial infusion - first described by Klopp-is a simpler procedure with a different set of indications. This method is not considered here.

\section{Literature}

The first attempt to attain a high concentration of cytotoxic agent in a tumour was made by Klopp et al. (1950) after observing the local effects of an accidental injection of $\mathrm{HN}_{2}$ into the brachial artery. 